Diabetologia 8, 381-384 (1972)

(C) by Springer-Verlag 1972

\title{
A Contribution to the Interpretation of the Oral Glucose Tolerance (OGTT)
}

\author{
M. Karp*, M. Brown**, Z. Laron* \\ Pediatric Metabolic and Endocrine Service*, Rogoff-Wellcome Medical Research Institute, Beilinson Hospital, \\ Petah Tiqva, and Department of Statistics**, Tel Aviv University, Israel \\ Received: July 27, 1972, accepted: August 24, 1972
}

\begin{abstract}
Summary. An oral glucose tolerance test was performed in 90 subjects aged $8-20$ years. Fifty subjects were normal controls. Twenty subjects had juvenile diabetes. These subjects were subdivided into two subgroups according to their insulin response: A group of 10 patients with no insulin response who subsequently required insulin treatment, and another group of 10 patients with delayed insulin response who subsequently were treated with diet and/or oral hypoglycaemic agents. Twenty subjects were obese, 10 of whom had normal glucose tolerance and 10 had glucose intolerance. It was found that the area under the glucose curve as calculated by fitting a quadratic function to the recorded values can discriminate between the glucose intolerance of the 4 groups of patients as compared to the normal controls. As to the insulin response, it was found that the area under the insulin curve is not sufficient to express the delayed insulin response found in the juvenile diabetics who subsequently did not need treatment with insulin.
\end{abstract}

Contribution à l'interprétation du test oral de tolérance au glucose (OGTT)

Résumé. 90 sujets de 8 à 20 ans ont subi un test oral do tolérance au glucose. 50 sujets étaient des témoins. 20 sujets avaient un diabète jeune. Ces sujets étaient subdivisés en deux groupes selon leur réponse d'insuline: un groupe de 10 maladés sans réponse d'insuline qui par la suite devaient subir un traitement à l'insuline, un autre groupe de 10 malades avec une réponse retardée d'insuline qui par la suite étaient traités par régime et/ou par des substances orales hypoglycémiantes. 20 malades étaient obèses : 10 avaient une tolérance normale au glucose et 10 une intolérance au glucose. On a trouvé quo la surface comprise sous la courbe de glucose caloulée en ajustant une fonction carrée aux valeurs notées peut bien différencier l'intolérance au glucose des 4 groupes de malados par comparaison avec les témoins. En ce qui concerne la réponse d'insuline, il a été trouvé que la surface comprise sous la courbe d'insuline est insuffisante à exprimer la réponse d'insuline retardée chez les diabétiques jeunes qui par la suite ne nécessitaient pas de traitement à l'insuline.

Ein Beitrag zur Interpretation des oralen Glucosetoleranztestes (OGTT)

Zusammenfassung. Bei 90 Personen zwischen 8 bis 20 Jahren wurde ein oraler Glucosetoleranztest durchgeführt. 50 Personen waren normale Kontrollen. Zwanzig Personen hatten einen juvenilen Diabetes. Diese Patienten wurden in zwei Gruppen entsprechend ihrer Insulinantwort unterteilt: in eine Gruppe von 10 Patienten ohne Insulinantwort, die eine anschließende Insulinbehandlung erforderte, und in eine zweite Gruppe von 10 Patien ten mit einer verspäteten Insulinantwort, die anschlieBend mit Diät und/oder oralen Antidiabetica behandelt wurde. Zwanzig Personen waren übergewichtig, zehn davon hatten eine normale und zehn eine schlechte Glucosetoleranz. Es wurde festgestellt, daß die Fläche unter der Glucosekurve, wenn sie durch das Angleichen einer quadratischen. Funktion an die erhaltenen Werte berechnet wurde, gut die 4 Patientengruppen von den normalen Kontrollen zu unterscheiden vermag. In bezug auf die Insulinantwort wurde gefunden, daB die Fläche unter der Insulinkurve nicht ausreicht, um die verspätete Insulinantwort bei jugendlichen Diabetikern ohne nachfolgende Behandlung, darzustellen.

Key words: Glucose intolerance. Insulin response. Juvenile Diabetes. Obesity. Oral glucose tolerance test.

\section{Introduction}

The interpretation of the oral glucose tolerance test in the diagnosis of diabetes mellitus and other disorders in carbohydrate metabolism is still a matter of dispute. Reliance has been placed on changes in blood glucose concentrations alone and several criteria for the diagnosis of diabetes mellitus have been established along these lines such as the criteria of Fajans and Conn [3], the Wilkerson Point System [13], the criteria of the University Group Diabetes Program [6], the

* Presented in part at the International Symposium, Commemorating the 50th Anniversary of Insulin; Impact of Insulin on Metabolic Pathways, Experimental and Clinical Aspects, Jerusalem, October 1971. criteria of the committee on statistics of the American Diabetes Association [2] and the method described by Kobberling et al. [7]. The introduction of a specific immunoassay for measurement of plasma insulin has resulted in considerable knowledge concerning the plasma insulin-glucose relationship [8, 9, 12].

The purpose of this study was to add information regarding the behaviour of the blood glucose and the plasma insulin concentrations during an oral glucose tolerance test in normal, diabetic and obese children and adolescents, by comparing the peak values, at different times, with the area under the glucose and insulin curves.

1 These coefficients were obtained using the computer which selected the best fit for expressing the area under the curve. 
Table 1. Oral glucose tolerance test: Blood sugar values

\begin{tabular}{|c|c|c|c|c|c|c|c|c|}
\hline \multirow{3}{*}{\multicolumn{2}{|c|}{$\begin{array}{l}\text { Subjects } \\
\text { Group No. }\end{array}$}} & \multicolumn{7}{|c|}{ Blood sugar $\mathrm{mg} / 100 \mathrm{ml}[$ mean \pm S.D. (Range) $]$} \\
\hline & & \multirow{2}{*}{$\underset{0}{\operatorname{Time}}(\mathrm{min})$} & \multirow[b]{2}{*}{30} & \multirow[b]{2}{*}{60} & \multirow[b]{2}{*}{90} & \multirow[b]{2}{*}{120} & \multirow[b]{2}{*}{150} & \multirow[b]{2}{*}{180} \\
\hline & & & & & & & & \\
\hline 1 & 50 & $\begin{array}{c}85 \pm 7 \\
(72=99)\end{array}$ & $\begin{array}{l}125 \pm 15 \\
(98-156)\end{array}$ & $\begin{array}{l}116 \leqq 10 \\
(98-144)\end{array}$ & $\begin{array}{l}107 \pm 12 \\
(88-167)\end{array}$ & $\begin{array}{c}96 \pm \quad 6 \\
(82-115)\end{array}$ & $\begin{array}{c}90 \pm c \\
(67-113)\end{array}$ & $\begin{array}{c}86 \pm \quad 7 \\
(68-107)\end{array}$ \\
\hline 2 & 10 & $\begin{array}{c}212 \pm 32^{\mathrm{b}} \\
(163-263)\end{array}$ & $\begin{array}{c}301 \pm 69^{\mathrm{b}} \\
(178-416)\end{array}$ & $\begin{array}{c}398 \leqq 90^{\mathrm{b}} \\
(215 \pm 486)\end{array}$ & $\begin{array}{c}440 \pm 77^{\mathrm{b}} \\
(281-524)\end{array}$ & $\begin{array}{c}440 \pm 83^{\mathrm{b}} \\
(290-534)\end{array}$ & $\begin{array}{c}461 \pm 68^{\mathrm{b}} \\
(360-532)\end{array}$ & $\begin{array}{r}441 \pm 86^{b} \\
(270-528)\end{array}$ \\
\hline 3 & 10 & $\begin{array}{c}148 \pm 44^{b} \\
(88-228)\end{array}$ & $\begin{array}{c}234 \pm 43^{\mathrm{b}} \\
(154-298)\end{array}$ & $\begin{array}{c}282 \pm 35^{\mathrm{b}} \\
(234-341)\end{array}$ & $\begin{array}{c}312 \pm 42^{\mathrm{b}} \\
(254-366)\end{array}$ & $\begin{array}{c}313 \pm 40^{\mathrm{b}} \\
(260-366)\end{array}$ & $\begin{array}{c}311 \pm 46^{b} \\
(254-397)\end{array}$ & $\begin{array}{c}317 \pm 50^{\mathrm{b}} \\
(243-403)\end{array}$ \\
\hline 4 & 10 & $\begin{array}{l}(91 \pm 7 \\
(79-101\end{array}$ & $\begin{array}{c}124 \pm 10 \\
(113=145)\end{array}$ & $\begin{array}{l}136 \pm 11^{\mathrm{a}} \\
119-152)\end{array}$ & $\begin{array}{r}126 \pm 8^{a} \\
115-142)\end{array}$ & $\begin{array}{l}105 \pm 5 \\
(96-112\end{array}$ & $\begin{array}{r}97 \pm \quad 6 \\
(88-102)\end{array}$ & $\begin{array}{c}91 \pm 6 \\
(81=98)\end{array}$ \\
\hline 5 & 10 & $\begin{array}{l}103 \pm 16 \\
(79-126)\end{array}$ & $\begin{array}{c}135 \pm 14 \\
(118-158)\end{array}$ & $\begin{array}{c}180 \pm 11^{b} \\
(167-198)\end{array}$ & $\begin{array}{c}201 \pm 15^{b} \\
(182-228)\end{array}$ & $\begin{array}{c}170 \pm 13^{b} \\
(143-186)\end{array}$ & $\begin{array}{c}139 \pm 11^{\mathrm{b}} \\
(118-150)\end{array}$ & $\begin{array}{l}115 \pm 9^{a} \\
(98-131)\end{array}$ \\
\hline
\end{tabular}

a Significantly different from Group 1 at $p<0.05$.

b Significantly different from Group 1 at $p<0.01$.

c For details see text.

Table 2. Oral glucose tolerance test: Plasma insulin values

\begin{tabular}{|c|c|c|c|c|c|c|c|c|}
\hline \multirow{2}{*}{\multicolumn{2}{|c|}{$\begin{array}{l}\text { Subjects } \\
\text { Group No. }\end{array}$}} & \multicolumn{7}{|c|}{ Plasma insulin $\mu \mathrm{U} / \mathrm{ml}[$ mean \pm S.D. (Range)] } \\
\hline & & ${ }_{0}^{\text {Time }}(\mathrm{min})$ & 30 & 60 & 90 & 120 & 150 & 180 \\
\hline 1 & 50 & $\begin{array}{c}23 \pm 9 \\
(10-55)\end{array}$ & $\begin{array}{c}117 \pm 46 \\
(57-200)\end{array}$ & $\begin{array}{l}105 \pm 30 \\
(60-180)\end{array}$ & $\begin{array}{c}80 \pm 23 \\
(35-147)\end{array}$ & $\begin{array}{c}64 \pm 20 \\
(25=148)\end{array}$ & $\begin{array}{c}49 \pm \begin{array}{c}17 \\
(21-120)\end{array}\end{array}$ & $\begin{array}{c}27 \pm 12 \\
(12-70)\end{array}$ \\
\hline 2 & 10 & $\begin{array}{c}23 \pm 7 \\
(13-33)\end{array}$ & $\begin{array}{l}23 \pm 10^{b} \\
(11=40)\end{array}$ & $\begin{array}{c}22 \pm 10^{\mathrm{b}} \\
(9 \pm 34)\end{array}$ & $\begin{array}{l}21 \pm 8^{b} \\
(12 \pm 33)\end{array}$ & $\begin{array}{l}21 \pm 9^{\mathrm{b}} \\
(12 \pm 38)\end{array}$ & $\begin{array}{l}25 \pm 19^{\mathrm{a}} \\
(11-43)\end{array}$ & 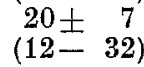 \\
\hline 3 & 10 & $\begin{array}{c}21 \pm 4 \\
(15-28)\end{array}$ & $\begin{array}{c}65 \pm 22^{b} \\
(33-110)\end{array}$ & $\begin{array}{l}75 \pm 23^{\mathrm{b}} \\
(56-123)\end{array}$ & $\begin{array}{c}72 \pm 32 \\
(45-149)\end{array}$ & $\begin{array}{c}57 \pm 21 \\
(38-100)\end{array}$ & $\begin{array}{c}55 \pm 34 \\
(31-138)\end{array}$ & $\begin{array}{c}50 \pm 44 \\
(20-150)\end{array}$ \\
\hline 4 & 10 & $\begin{array}{c}17 \pm 4 \\
(12 \pm 24)\end{array}$ & $\begin{array}{c}168 \pm 31^{\mathrm{b}} \\
(123-200)\end{array}$ & $\begin{array}{c}182 \pm 19^{\mathrm{b}} \\
(148-200)\end{array}$ & $\begin{array}{c}177 \pm 30^{\mathrm{b}} \\
(141=200)\end{array}$ & $\begin{array}{c}151 \pm 37^{b} \\
(100-200)\end{array}$ & $\begin{array}{r}77 \pm 25^{\mathrm{a}} \\
(43 \pm 120)\end{array}$ & $\begin{array}{c}41 \pm 19 \\
(21=86)\end{array}$ \\
\hline 5 & 10 & $\begin{array}{c}19 \pm 4 \\
(12-25)\end{array}$ & $\begin{array}{c}140 \pm 52^{a} \\
(56-200)\end{array}$ & $\begin{array}{c}167 \pm 27^{b} \\
(126-200)\end{array}$ & $\begin{array}{c}175 \pm 28^{b} \\
(117-200)\end{array}$ & $\begin{array}{c}149 \pm 23^{b} \\
(120-200)\end{array}$ & $\begin{array}{c}96 \pm 22^{\mathrm{b}} \\
(71-142)\end{array}$ & $\begin{array}{c}49 \pm 12 \\
(38-72)\end{array}$ \\
\hline
\end{tabular}

a Significantly different from Group 1 at $p<0.05$.

b Significantly different from Group 1 at $p<0.01$.

\section{Materials and Methods}

A standard oral glucose tolerance test was performed in 90 subjects aged 8 to 20 years. The glucose dose was $1.75 \mathrm{~g} / \mathrm{kg}$ with a maximum of $100 \mathrm{~g}$. Fifty subjects were normal controls (Group 1). Twenty subjects had juvenile diabetes. According to their insulin response during OGTT they were subsequently divided into two groups:

A. 10 patients with no insulin response (Group 2). These patients required insulin treatment.

B. 10 patients with some insulin response (Group 3). These patients subsequently were treated by diet and/or oral hypoglycaemic agents.

Twenty subjects were obese who according to their glucose tolerance were divided into 2 groups:

A. 10 subjects with normal glucose tolerance (Group 4) and B. 10 subjects with glucose intolerance (Group 5).

All tests were performed before any treatment was initiated. Glucose intolerance in the obese subjects was defined according to the criteria of Fajans and Conn [1], namely a blood sugar concentration of over $160 \mathrm{mg} / 100$ $\mathrm{ml}$ at $1 \mathrm{~h}$ and a $2 \mathrm{~h}$ value of $120 \mathrm{mg} / 100 \mathrm{ml}$ or more. Obesity was defined if the skinfold thickness over the subscapular and the triceps regions, measured with the Harpenden Caliper, was over $25 \mathrm{~mm}$. The patients in Group 3 were treated with diet and/or sulfonylurea drugs for over one year. Their clinical course will be published elsewhere.

The oral glucose tolerance tests (OGTT) were performed on ambulatory patients after an overnight fast.
Table 3. Oral glucose tolerance test, glucose and insulin area $\stackrel{\text { Area }}{ } \stackrel{7 \mathrm{Y}_{0}+12 \mathrm{Y}_{30}+15 \mathrm{Y}_{60}+16 \mathrm{Y}_{90}+15 \mathrm{Y}_{120}+12 \mathrm{Y}_{150}+7 \mathrm{Y}_{180}}{ }$ $=\frac{14}{14}$

\begin{tabular}{|c|c|c|c|}
\hline Group & No. & $\begin{array}{l}\text { Glucose area } \\
\text { (Mean } \pm \text { S.D.) }\end{array}$ & $\begin{array}{l}\text { Insulin area } \\
\text { (Mean } \pm \text { S.D.) }\end{array}$ \\
\hline 1 & 50 & $620+35$ & $440+113$ \\
\hline 2 & 10 & $2382+394^{\mathrm{a}}$ & 131 土 $44^{2}$ \\
\hline 3 & 10 & $1694 \pm 224^{\mathrm{a}}$ & $363 \pm 133$ \\
\hline 4 & 10 & $682 \pm 38$ & $798 \pm 127 \mathrm{a}$ \\
\hline 5 & 10 & $949 \pm 64^{\mathrm{a}}$ & $775 \pm 122^{a}$ \\
\hline
\end{tabular}

a $p<0.01$.

An indwelling needle was inserted into the antecubital vein and blood was withdrawn at $0,30,60,90,120,150$, and $180 \mathrm{~min}$. Blood glucose was measured by the ferricyanide reduction method on a Technicon Autoanalyzer. Plasma insulin was assayed by double antibody radioimmunoassay, using a modification of the method of Hales and Randle [5]. The results obtained were analyzed with the aid of the Tel Aviv University CDC 6600 computer.

\section{Results}

Table 1 and Fig. 1 show the blood glucose concentrations in the five groups studied. The fasting values 
were high in the patients with both types of juvenile diabetes. At 60 and $90 \mathrm{~min}$ the glucose concentration in the diabetic subjects and in the two groups of the obese subjects was higher than in the normal group,

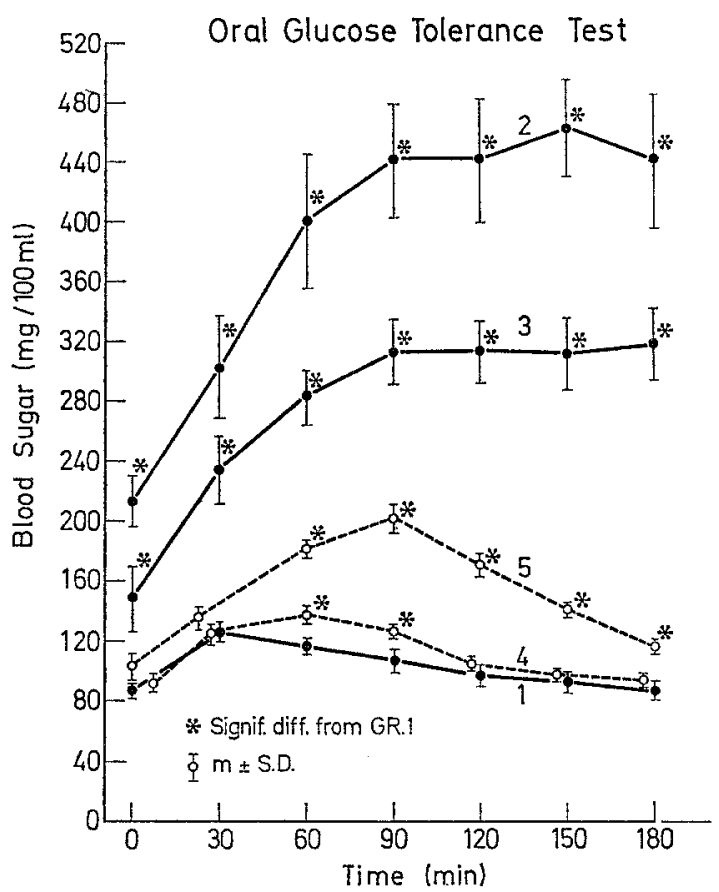

Fig. 1. Blood sugar response to oral glucose tolerance in normal subjects, patients with juvenile diabetes and subjects with obesity (mean \pm S.D.) in the diabetic subjects and the obese subjects with glucose intolerance. Table 2 and Fig. 2 show the plasma insulin levels in the subjects studied. The fasting plasma insulin level was similar in the various

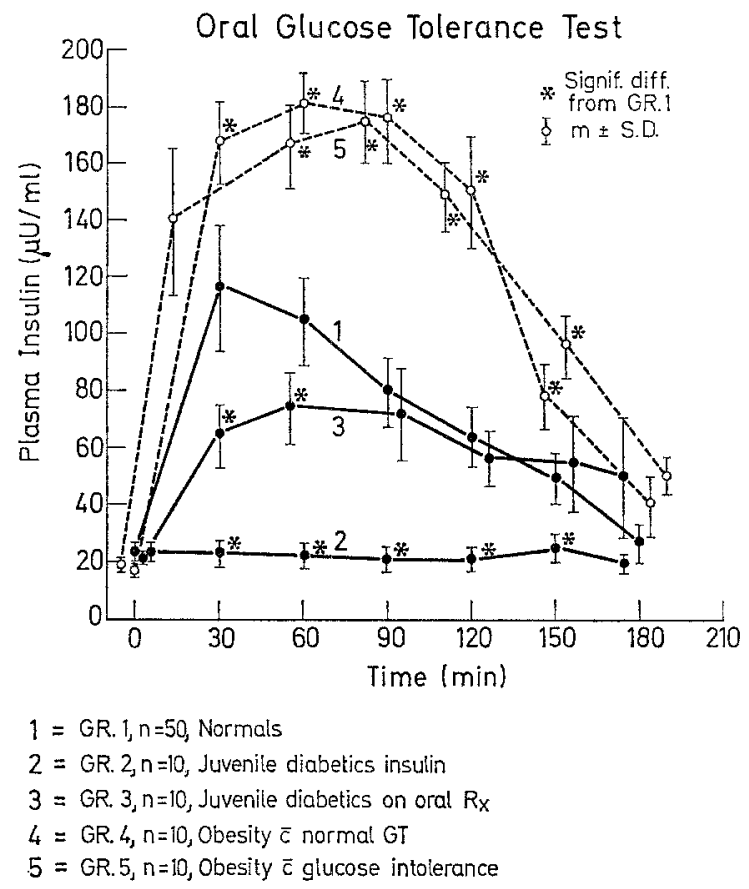

Fig. 2. Plasma insulin response to oral glucose tolerance in normal subjects, patients with juvenile diabetes and subjects with obesity

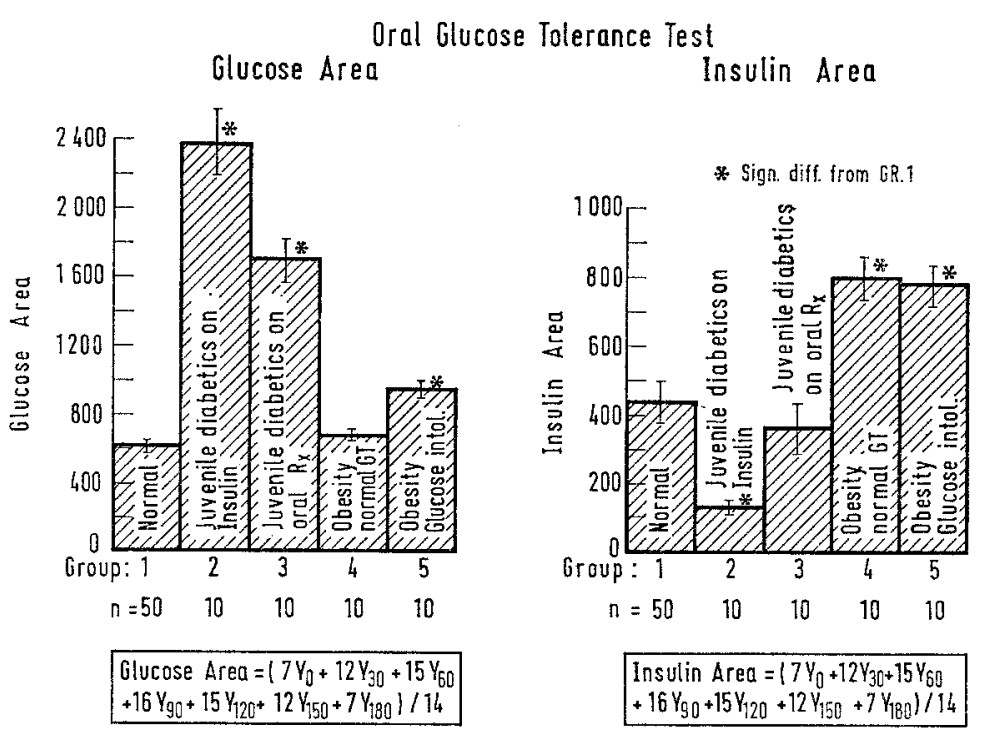

Fig. 3. Glucose and insulin area in oral glucose tolerance test in normal subjects, patients with juvenile diabetes and subjects with obesity

although in the obese subjects with normal glucose tolerance (Gr. 4) it was within the normal range, according to the criteria of Fajans and Conn [1]. At 120 and $180 \mathrm{~min}$ the glucose concentration was still high groups ranging from 19 to $23 \mu \mathrm{U} / \mathrm{ml}$. At 30 and $60 \mathrm{~min}$ there was a significant difference between the normal control group and the four other groups. The diabetic patients of Gr. 2 had the lowest insulin concentrations 
and the obese subjects (Gr. 4 and 5) had the highest concentrations. The increased levels in these groups returned to values comparable to the normal subjects at $180 \mathrm{~min}$.

To calculate the area under the glucose or insulin curve, it was decided to approximate the seven recorded values by a quadratic polynomial as a function of time and then integrate the area under the curve. The formula for area $A$, then becomes:

$A=\frac{7 Y_{0}+12 Y_{30}+15 Y_{60}+16 Y_{90}+15 Y_{120}+12 Y_{150}+7 Y_{180}}{14}$

where $Y_{0}$ to $Y_{180}$ are the individual glucose or insulin concentrations at 0 to $180 \mathrm{~min}$ respectively. The quadratic polynomial approximation was chosen for several pragmatic reasons:

1) The sum of all seven values does not give a good indication of area 2) the use of a higher order polynomial yields coefficients which are difficult to use for routine work 3) an exact fit (a sixth-order polynomial) puts relatively high weight on three observations and low on the others, such that errors of observations in any of the three observations are highly magnified by the expression for area 4) the above formula gives a good approximation for area and is easy to use although it is not optimal.

Table 3 and Fig. 3 show the results obtained by using formula 1 .

The patients with juvenile diabetes and the obese subjects of Gr. 5, showed a significant glucose intolerance, most distinctly in the diabetic patients. As to the insulin area, both groups of patients with obesity had distinct hyperinsulinism in contrast to the insulinopenia in the diabetic patients who required treatment with insulin (Gr. 2). It is to be noted that there was no difference in the insulin area between the normal subjects and the patients with diabetes of Gr. 3. Even so, the mean of the individual values in the diabetics of that group at 30 and 60 min were lower than in the normal subjects. This is explained by the wide range of concentrations and the overlapping of some individual results, at 30 and 60 min, as shown in Table 2.

\section{Discussion}

The glucose and the insulin responses to oral glucose were expressed as a quadratic function presented by a relative simple formula measuring the area under the eurves.

As expected, the patients with juvenile diabetes with no insulin reserve had the most marked glucose intolerance. The patients from Gr. 3 had an insulin response which, when expressed as area, was not different from the normal controls. Nevertheless the mean, levels at 30 and $60 \mathrm{~min}$ were significantly lower than in the normal controls. Therefore this delayed insulin response cannot be adequately expressed by the area under the curve. It is still questionable if the delayed insulin response has a physiologic meaning [10] and is responsible for the development of glucose intolerance. The calculation of the insulinogenic index, as suggested by Seltzer et al. [12], seemed superfluous therefore.

It is noteworthy that the obese children with or without glucose intolerance had the same degree of hyperinsulinism, a well known phenomenon [1].

The use of continuous measurements to check for a tendency towards the development of diabetes can only be tested in a prospective study. Its application in the cases of mild maturity onset diabetes [12] and asymptomatic chemical juvenile diabetes $[4,11]$ with delayed insulin response, remains to be tested as well.

\section{References}

1. Chiumello, G.: Is obesity a factor predisposing to juvenile diabetes? In: Habilitation and rehabilitation of juvenile diabetics, pp. 61-72. Z. Laron, Ed., H. E. Stenfert Kroese, N. V. Leiden; 1970.

2. Committee on statistics of the American Diabetes Association Standardization of the oral glucose tolerance test. Diabetes 18, 229-310 (1969).

3. Fajans, S.S., Conn, J.S.: The early recognition of diabetes mellitus. Ann. N.Y.Acad. Sci. 82, 208-218 (1959).

4. Fajans, S.S., Floyd, J.C., Pek, S., Conn. J.W.: The course of asymptomatic diabetes in young people as determined by levels of blood glucose and plasma insulin. Trans. Ass. Amer. Phycns. 82, $211-224$ (1969).

5. Hales, C.N., Randle, R.J.: Immunoassay of insulin with insulin antibody precipitate. Biochem. J. 88, 137-146 (1963).

6. Klimt, C.R., Meinert, L.L., Miller, M., Knowles, H. C., Jr.: University group diabetes program (UGDP). A study of the relationship of therapy to vascular and other complications of diabetes. In: Tolbutamide after ten years. Brook Lodge Symposium, August 1967, pp. 261-269. Excerpta Med. Int. Congress Series. No. 149. New York 1967.

7. Kobberling, J., Creutzfeldt, W.: Comparison of different methods for the evaluation of the oral glucose tolerance test. Diabetes 19, 870-873 (1970).

8. Perley, M., Kipnis, D.M. : Plasma insulin response to glucose and tolbutamide of normal weight and obese diabetic and non diabetic subjects. Diabetes 15, 867$874(1966)$.

9. Reaven, G., Miller, R. : Study of relationship between glucose and insulin responses to an oral glucose load. in man. Diabetes 17, 560-569 (1968).

10. Reaven, G.M., Shen, S.W., Silvers, A., Farquhar, J. W.: Is there a delay in the plasma insulin response of patients with chemical diabetes mellitus? Diabetes $20,416-423$ (1971).

11. Rosenbloom, A.L.: Insulin response of children with chemical diabetes mellitus. New Engl. J. Med. 282, 1228-1231 (1970).

12. Seltzer, H.S., Allen. E.W., Herron, A.L., Jr., Brennan, M.T.: Insulin secretion in response to glycemic stimulus: relation of delayed initial release to carbohydrate intolerance in mild diabetes. J. clin. Invest. 46, 323-335 (1967)

13. Wilkerson, H.L.C.: Diagnosis, oral glucose tolerance test: In: Diabetes mellitus, diagnosis and treatment, pp. 31-34. New York: American Diabetes Association 1964.

Zvi Laron, M.D.

Professor of Paediatric Endocrinology

Beilinson Hospital

Medical Center

Tel-Aviv/Israel 